\title{
PENERAPAN PEMBELAJARAN COOPERATIVE E-LEARNING UNTUK MENINGKATKAN HASIL BELAJAR TEMATIK SISWA KELAS V SD NEGERI 002 RAMBAH SAMO
}

\author{
ELLA ANDESTY ${ }^{1}$, VIDA ANGGRAINI ${ }^{2}$, REJEKI ${ }^{3}$ \\ ${ }^{1,2,3}$ Pendidikan Guru Sekolah Dasar STKIP ROKANIA \\ 1ellaandes291@gmail.com \\ 2vidaanggraini86@gmail.com \\ 3 rejekijekimuria87@gmail.com
}

\begin{abstract}
Abstrak
Penelitian ini bertujuan untuk mengetahui bahwa penerapan pembelajaran Cooperative ELearning untuk meningkatkan hasil belajar tematik siswa kelas V SD Negeri 002 Rambah Samo. Latar belakang yang mendasari penelitian ini adalah ketidak tercapaian tujuan pembelajaran yang tergambar dari nilai ulangan harian siswa pada pembelajaran tematik yang masih di bawah nilai KKM 75. Subjek pada penelitian tindakan kelas ini adalah siswa SD Negeri 002 Rambah Samo yang berjumlah 24 orang, terdiri atas 16 siswa perempuan dan 8 siswa lakilaki. Teknik analisis data yang digunakan pada penelitian ini adalah dengan menggunakan beberapa instrumen berupa lembar soal dan lembar pengamatan aktivitas siswa. Hasil penelitian ini dapat dilihat dari pertemuan 1 siklus 1 siswa yang tuntas sebanyak $58 \%$ (14 siswa) dan 42\% (10 siswa) tidak tuntas dengan nilai rata-rata 66,25, meningkat pada pertemuan 2 yaitu dengan jumlah siswa yang tuntas sebanyak $67 \%$ (16 siswa) dan yang tidak tuntas berjumlah $33 \%$ (8 siswa) dengan nilai rata-rata 75 . Pada siklus 2 pertemuan 1 yang tuntas sebanyak $83 \%$ (20 siswa) dan yang tidak tuntas sebanyak $17 \%$ (4 siswa) dengan nilai rata-rata 85,4, kemudian mengalami peningkatan pada pertemuan 2 yaitu dengan jumlah yang tuntas sebanyak $92 \%$ (22 siswa) dan yang tidak tuntas sebanyak $8 \%$ (2 siswa) dengan nilai rata-rata 90,6. Dengan adanya peningkatan hasil belajar maka terjadi peningkatan aktivitas guru dan siswa. Berdasarkan hasil belajar tersebut dapat dikatakan terjadi peningkatan hasil belajar siswa dari siklus 1 ke siklus 2 sebesar $25 \%$. Apabila dilihat dari data yang sudah didapat bahwa yang lulus telah melebihi indikator keberhasilan. Maka dapat disimpulkan bahwa penerapan pembelajaran Cooperative E-Learning untuk meningkatkan hasil belajar Tematik siswa kelas V SD Negeri 002 Rambah Samo telah berhasil.
\end{abstract}

Kata Kunci: Cooperative E-Learning, Hasil Belajar, Tematik.

\begin{abstract}
This study aims to determine that the application of Cooperative E-Learning learning to improve thematic learning outcomes of fifth grade students of SD Negeri 002 Rambah Samo. The background that underlies this research is the failure to achieve learning objectives as illustrated by the daily test scores of students in thematic learning which are still below the KKM score of 75. The subjects in this classroom action research are students of SD Negeri 002 Rambah Samo, totaling 24 people, consisting of 16 female students and 8 male students. The data analysis technique used in this study was to use several instruments in the form of question sheets and student activity observation sheets. The results of this study can be seen from the first meeting of cycle 1 students who completed as many as $58 \%$ (14 students) and $42 \%$ (10 students) did not complete with an average value of 66.25 , increasing at meeting 2 with the number of students who completed as many as $67 \%$ (16 students) and those who did not complete were $33 \%$ (8 students) with an average score of 75 . In cycle 2 , meeting $1,83 \%$ were completed (20 students) and 17\% (4 students) were incomplete with a score of an average of 85.4 , then increased at the second meeting, namely the number of students who completed $92 \%$ (22 students) and those who did not complete as many as $8 \%$ (2 students) with an average value of 90.6. With the increase in learning outcomes, there is an increase in teacher and student activities. Based on these learning outcomes, it can be said that there was an increase in student learning outcomes from cycle 1 to cycle 2 by $25 \%$. When viewed from the data that has been obtained that those who pass have exceeded the success indicators. So it
\end{abstract}


can be concluded that the application of Cooperative E-Learning learning to improve thematic learning outcomes for fifth grade students of SD Negeri 002 Rambah Samo has been successful.

Keywords: Cooperative E-Learning, Learning Outcomes, Thematic.

\section{PENDAHULUAN}

Proses pembelajaran di tingkat satuan pendidikan saat ini memakai Kurikulum 2013, sesuai dengan Permendikbud RI Nomor 24 Tahun 2016 ditetapkan sebagai perbaikan Kompetensi Inti dan Kompetensi Dasar yang menggunakan akomodasi prinsip-prinsip dengan tujuan untuk menguatkan proses belajar serta untuk menyesuaikan kurikulum berdasarkan perkembangan dan kebutuhan pendidikan saat ini. Keberhasilan pembelajaran dalam penerapan kurikulum 2013 perlu ditunjang dengan penggunaan Teknologi Informasi dan Komunikasi (TIK) sebagai sarana penyampaian materi pembelajaran dengan tujuan agar lebih mudah dipahami oleh siswa. Kemajuan TIK dalam penerapan K13 telah menciptakan pembelajaran berbasis internet atau online yang sering disebut dengan Electronic Learning $(E$ Learning). Riyanto (2010) mengatakan hakikat pembelajaran kooperatif adalah metode pembelajaran yang dirancang untuk melatih kecakapan akademis (academic skills), keterampilan sosial (social skills) dan interpersonal skill. Sedangkan defenisi e-learning menurut Sutanta (2014) merupakan suatu jenis sistem pembelajaran yang memungkinkan tercapainya bahan ajar ke siswa dengan menggunakan media internet, intranet atau media jaringan komputer lainnya.

Berdasarkan hasil pengamatan peneliti di SD Negeri 002 Rambah Samo sejak tanggal 01 September 2021 ada beberapa hal yang menjadi pusat perhatian dalam penelitian ini, yaitu pada hasil belajar tematik siswa yang masih di bawah rata-rata dan ada beberapa permasalahan di kelas seperti siswa yang keluar masuk saat pembelajaran, siswa ribut, kurang aktif dan siswa yang nilainya di bawah 75 sebagai KKM (Kriteria Ketuntasan Minimal). Hal ini dapat dilihat dari nilai rata-rata ulangan harian siswa yang masih cukup rendah, kemudian ada siswa yang berada di kelas tinggi namun kemampuan membaca dan menulisnya masih perlu diasah. Adapun beberapa faktor yang menyebabkan kondisi tersebut adalah pada proses pembelajaran dan juga belum adanya impementasi yang menyeluruh pada penggunaan digital dalam pembelajaran. Selain kendala dalam proses belajar mengajar di kelas yang masih menggunakan cara-cara konvensional, saat ini ditambah dengan kondisi wabah Covid-19 sehingga pembelajaran tatap muka pun dibatasi. Berikut persentase dari beberapa permasalahan yang timbul.

Tabel 1. Permasalahan di kelas

\begin{tabular}{|c|l|c|c|}
\hline No & \multicolumn{1}{|c|}{ Permasalahan } & Jumlah Siswa & Persentase \\
\hline 1 & Siswa kurang aktif & 9 & $37,5 \%$ \\
\hline 2 & Siswa ribut di kelas & 3 & $12,5 \%$ \\
\hline 3 & Siswa yang nilainya di bawah KKM & 10 & $41,6 \%$ \\
\hline 4 & Siswa yang belum lancar membaca & 2 & $8,3 \%$ \\
\hline \multicolumn{2}{r|}{ Jumlah } & 24 & $100 \%$ \\
\hline
\end{tabular}

Sumber: Observasi selama penelitian di Sekolah SD Negeri 002 Rambah Samo

Penerapan pembelajaran e-learning secara kooperatif diharapkan dapat meningkatkan hasil belajar siswa karena dengan belajar secara berkelompok siswa mampu mengembangkan kemampuan intelektual, sosial dan emosionalnya. Dengan menciptakan suasana belajar yang baru dan menyenangkan bagi siswa diharapkan pembelajaran dapat berlangsung secara efektif dan efisien, tercapai tujuan pembelajaran dan mendapat hasil belajar yang memuaskan meskipun terhalang oleh jarak. Kelebihan dari pembelajaran E-Learning adalah Tersedianya fasilitas e-moderating dimana guru dan siswa dapat berkomunikasi secara mudah melalui internet secara regular atau kapan saja, kegiatan berkomunikasi itu dilakukan dengan tanpa 
dibatasi oleh jarak dan waktu. berubahnya peran siswa dari yang biasanya pasif menjadi aktif, relatif lebih efisien dalam penyampaian materi dan efisien dalam penggunaan waktu.

Penelitian sejenis sudah pernah dilakukan oleh Annisa Nur Rahadian dengan judul "Peningkatan Hasil Belajar IPA Melalui Model E-Learning Dengan Media Video Pada Siswa Kelas IV MIN 4 Sukoharjo Tahun Pelajaran 2019/2020." Dalam penelitian tersebut diperoleh hasil pada pra siklus siswa yang tuntas KBM sebanyak $48,3 \%$ dan yang belum tuntas $51,7 \%$. Pada siklus I terdapat 24 siswa $(82,8 \%)$ yang tuntas dan 5 siswa $(17,2 \%)$ yang belum tuntas. Kemudian mengalami peningkatan pada siklus 2 jumlah siswa yang tuntas sebanyak $89,7 \%$ dan yang belum tuntas sebanyak $10,3 \%$. Pada penelitian tersebut dapat disimpulkan bahwa penerapan E-Learning dapat meningkatkan hasil belajar siswa Kelas IV MIN 4 Sukoharjo karena telah mencapai kriteria ketuntasan klasikal yaitu $85 \%$.

Berdasarkan latar belakang yang telah dipaparkan, maka rumusan masalah dalam penelitian ini adalah "Bagaimanakah penerapan pembelajaran Cooperative E-Learning Untuk meningkatkan hasil belajar tematik siswa kelas V SD Negeri 002 Rambah Samo ?"

\section{METODE PENELITIAN}

Bentuk penelitian ini adalah Penelitian Tindakan Kelas (PTK). Menurut Mulyasa (2009) PTK dapat diartikan sebagai penelitian tindakan yang dilakukan dengan tujuan untuk memperbaiki kualitas proses dan hasil belajar sekelompok peserta didik. Menurut Kunandar (dalam Iskandar 2008) penelitian tindakan (Action Research) merupakan suatu kegiatan yang dilakukan oleh Guru atau Bersama-sama dengan orang lain (kolaborasi) yang bertujuan untuk memperbaiki/meningkatkan mutu proses pembelajaran dikelasnya. Sedangkan menurut Arikunto dkk PTK merupakan suatu pencermatan terhadap kegiatan pembelajaran berupa sebuah tindakan, yang sengaja dimunculkan dan terjadi dalam sebuah kelas secara bersamaan. Berbagai pendapat para ahli mengenai pengertian PTK dapat disimpulkan bahwa Penelitian Tindakan Kelas adalah suatu cara, upaya atau tindakan yang dilakukan oleh guru di dalam kelas atau kelompoknya dalam rangka memperbaiki dan meningkatkan mutu pendidikan baik dalam proses maupun hasil pembelajarannya.

Penelitian ini dilaksanakan di SD Negeri 002 Rambah Samo sebanyak dua siklus. Subyek penelitian ini adalah siswa kelas V SD Negeri 002 Rambah Samo sebanyak 24 siswa. Teknik pengumpulan data dalam penelitian ini adalah dengan menggunakan metode observasi, wawancara, tes, dan dokumentasi. Sedangkan instrumen data yang digunakan peneliti pada Penelitian Tindakan Kelas ini adalah dengan melakukan observasi langsung terhadap subyek yang akan diteliti yaitu siswa kelas V SD Negeri 002 Rambah Samo dengan cara peneliti terlibat dan beraktivitas bersama-sama dalam kegiatan belajar mengajar, kemudian menggunakan beberapa item pertanyaan yang disusun peneliti guna untuk mewawancarai responden. Dalam hal ini sebagai respondennya adalah guru wali kelas V dan Kepala Sekolah SD Negeri 002 Rambah Samo.

Peneliti juga menggunakan instrument tes berupa soal-soal evaluasi sebagai alat untuk mengetahui hasil pemahaman dan hasil belajar siswa pada saat penelitian serta dokumentasi menggunakan kamera handphone untuk mengambil foto-foto kegiatan saat penelitian. Metode analisis data menggunakan analisis data deskriptif kualitatif. Sedangkan desain penelitian kelas ini terdiri dari dua siklus yang merupakan model PTK dari Arikunto. Setiap siklus terdiri atas empat tahap kegiatan, yaitu: (1) Perencanaan (planning), (2) Pelaksanaan (acting), (3) Pengamatan/Observasi (observing), dan (4) Refleksi/Evaluasi (reflecting). Bagan desain penelitian tindakan kelas pada penelitian ini dapat dilihat pada gambar 1 berikut. 


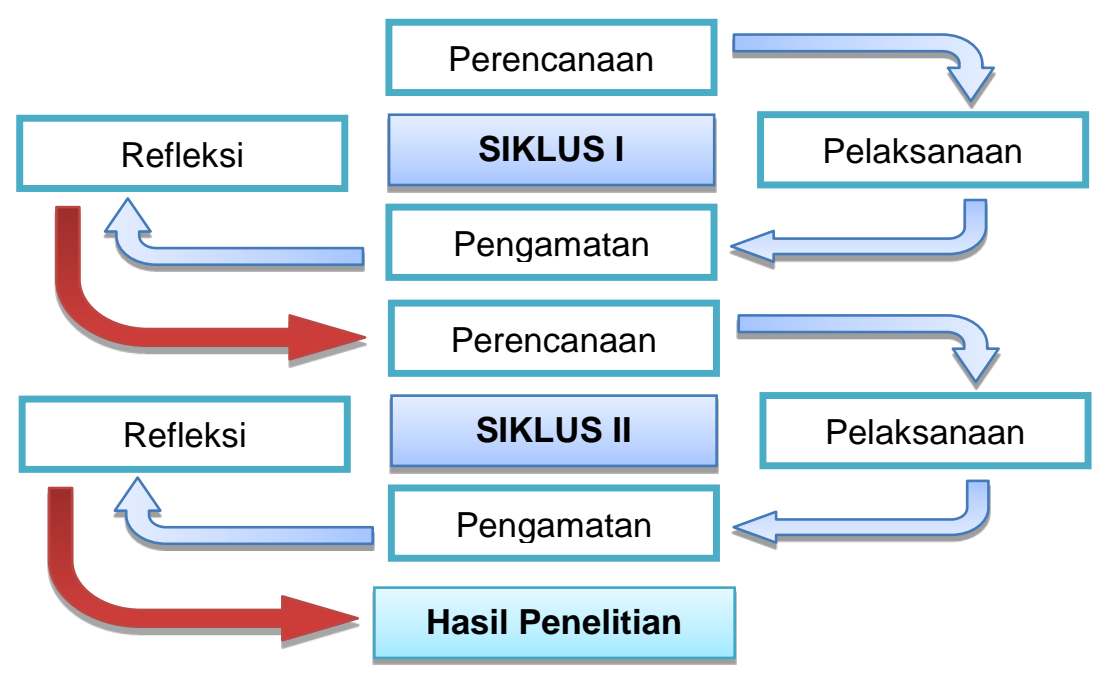

Gambar 1. Desain Siklus PTK Menurut Arikunto

\section{HASIL DAN PEMBAHASAN}

\section{Hasil Penelitian}

Penelitian ini dilaksanakan sebanyak dua siklus, dimana setiap siklus dilakukan dua kali pertemuan.

\section{a. Siklus 1}

Siklus 1 pertemuan 1 dilaksanakan pada hari Rabu, tanggal 01 September 2021 di kelas V SD Negeri 002 Rambah Samo yang berjumlah 24 siswa dengan rangkaian kegiatan belajar mengajar yang sudah tertuang dalam RPP (Rencana Pelaksanaan Pembelajaran) dimulai dari kegiatan awal penulis memberikan apersepsi, memberikan semangat dan memotivasi siswa, menyanyikan lagu nasional serta menyampaikan tujuan pembelajaran. Selanjutnya masuk ke kegiatan inti yaitu membahas materi pada Tema 3 Makanan Sehat, Subtema 1 Bagaimana Tubuh Mengolah Makanan, Pembelajaran 1. Sebelum masuk ke materi peneliti terlebih dahulu menyampaikan bagaimana langkah-langkah menggunakan aplikasi Classroom dengan menggunakan android. Selanjutnya peneliti menjelaskan tentang makanan sehat dengan berbantuan media audio visual yang ditampilkan menggunakan infocus. Selama pembelajaran berlangsung peneliti memberikan kesempatan kepada siswa untuk bertanya mengenai materi yang belum dipahami, kemudian siswa mengerjakan soal dalam bentuk tes yang sudah disiapkan dalam Classroom untuk mengetahui tingkat penguasaan materi yang baru dipelajari. Selanjutnya siswa dibantu oleh peneliti dalam mengerjakan soal tes di Classroom. Kegiatan penutup peneliti memberikan refleksi dan evaluasi secara umum mengenai materi yang sudah dipelajari kemudian menyimpulkan pembelajaran secara bersama dan peneliti pun memberikan tindak lanjut agar siswa tetap semangat dan rajin belajar di rumah.

Siklus 1 pertemuan 2 dilaksanakan pada hari Sabtu, tanggal 04 September 2021 di kelas dan rangkaian kegiatan pembelajaran yang sama, hanya pada kegiatan inti saja yang berbeda. Pada kegiatan inti di pertemuan 2 peneliti tetap menyampaikan langkah-langkah menggunakan aplikasi Classroom dengan menggunakan android. Langkah-langkah mengunduh materi pembelajaran dan soal-soal latihan di Classroom juga tetap disampaikan peneliti, dengan tujuan siswa-siswi semakin paham menggunakan aplikasi tersebut. Pada pertemuan 2 peneliti menjelaskan materi Tema 3 Makanan Sehat, Subtema 1 Bagaimana Tubuh Mengolah Makanan, pembelajaran 4. Pada kegiatan penutup peneliti juga memberikan soal-soal tes sebagai bahan evaluasi pemahaman siswa-siswi mengenai materi pembelajaran yang baru saja dipelajari dengan menggunakan E-Learning. Adapun hasil evaluasi siswa pada siklus 1 pertemuan 1 dan 2 dapat dilihat pada tabel 2 berikut. 
Tabel 2. Data Hasil Belajar Siswa Siklus 1

\begin{tabular}{|c|c|c|c|c|c|c|c|}
\hline \multirow{2}{*}{ No } & \multirow{2}{*}{ Nama } & \multirow{2}{*}{$\begin{array}{c}\text { Nilai Siklus } \\
1 \\
\text { Pertemuan } \\
1\end{array}$} & \multicolumn{2}{|c|}{$\begin{array}{c}\text { Ketuntasan Pert } \\
1\end{array}$} & \multirow{2}{*}{$\begin{array}{c}\text { Nilai Siklus } \\
1 \\
\text { Pertemuan } \\
2\end{array}$} & \multicolumn{2}{|c|}{$\begin{array}{c}\text { Ketuntasan Pert } \\
2\end{array}$} \\
\hline & & & Tuntas & $\begin{array}{l}\text { Tidak } \\
\text { Tuntas }\end{array}$ & & Tuntas & $\begin{array}{l}\text { Tidak } \\
\text { Tuntas }\end{array}$ \\
\hline 1 & $\overline{A A}$ & 60 & & TT & 75 & $T$ & \\
\hline 2 & $\mathrm{Al}$ & 85 & $T$ & & 90 & $T$ & \\
\hline 3 & AR & 55 & & TT & 60 & & TT \\
\hline 4 & AR & 50 & & TT & 70 & & TT \\
\hline 5 & AS & 65 & & TT & 70 & & TT \\
\hline 6 & DHR & 85 & $T$ & & 90 & $\mathrm{~T}$ & \\
\hline 7 & DSA & 50 & & TT & 80 & $\mathrm{~T}$ & \\
\hline 8 & EID & 75 & $T$ & & 85 & $\mathrm{~T}$ & \\
\hline 9 & HAZ & 80 & $T$ & & 85 & $\mathrm{~T}$ & \\
\hline 10 & HIR & 75 & $\mathrm{~T}$ & & 85 & $\mathrm{~T}$ & \\
\hline 11 & $\mathrm{KG}$ & 80 & $T$ & & 80 & $T$ & \\
\hline 12 & MA & 75 & $T$ & & 85 & $\mathrm{~T}$ & \\
\hline 13 & MA & 75 & $T$ & & 80 & $\mathrm{~T}$ & \\
\hline 14 & MAPT & 85 & $\mathrm{~T}$ & & 90 & $\mathrm{~T}$ & \\
\hline 15 & MAS & 75 & $T$ & & 90 & $\mathrm{~T}$ & \\
\hline 16 & $\mathrm{NH}$ & 45 & & TT & 65 & & TT \\
\hline 17 & RR & 80 & $T$ & & 85 & $T$ & \\
\hline 18 & SA & 85 & $\mathrm{~T}$ & & 85 & $\mathrm{~T}$ & \\
\hline 19 & SA & 80 & $T$ & & 85 & $T$ & \\
\hline 20 & SS & 75 & $\mathrm{~T}$ & & 80 & $T$ & \\
\hline 21 & TFW & 55 & & TT & 65 & & TT \\
\hline 22 & W & 70 & & TT & 70 & & TT \\
\hline 23 & YF & 55 & & TT & 60 & & TT \\
\hline 24 & $\mathrm{ZH}$ & 45 & & TT & 70 & & TT \\
\hline & a-Rata & 66,25 & & & 75 & & \\
\hline \multicolumn{3}{|c|}{ Jumlah } & $\begin{array}{c}14 \\
\text { Siswa }\end{array}$ & $\begin{array}{c}10 \\
\text { Siswa }\end{array}$ & & $\begin{array}{c}16 \\
\text { Siswa }\end{array}$ & 8 Siswa \\
\hline \multicolumn{3}{|c|}{ Persentase \% } & $58 \%$ & $42 \%$ & & $67 \%$ & $33 \%$ \\
\hline
\end{tabular}

Sumber: Hasil Olahan Data 2021

Berdasarkan tabel 2 di atas, jumlah hasil evaluasi siswa pada siklus 1 pertemuan 1 yang tuntas sebanyak 14 siswa yaitu 58\% dengan nilai rata-rata 66,25 sedangkan yang tidak tuntas sebanyak 10 siswa yaitu $42 \%$. Hasil evaluasi siswa meningkat pada pertemuan kedua yaitu dengan jumlah 16 Siswa tuntas yaitu 67\% dengan nilai rata-rata 75 dan yang tidak tuntas sebanyak $33 \%$. Banyaknya siswa yang 
tidak tuntas pada siklus 1 pertemuan 1 ini disebablkan beberapa kendala yang diantaranya adalah karena media Classroom baru pertama kali digunakan di kelas $\mathrm{V}$ SD Negeri 002 Rambah Samo, sehingga siswa masih kurang memahami cara serta langkah-langkah penggunaan dari setiap fungsi menu dalam media Classroom. Hal ini tentu menjadi salah satu faktor penghambat lancarnya pembelajaran dikarenakan dalam mengakses materi dan soal-soal latihan harus bisa mengoperasikan aplikasi Classroom. Jika dilihat dari hasil evaluasi pertemuan 1 dan 2, pada pertemuan 2 sudah ada peningkatan 12\%, karena di pertemuan 2 ini siswa-siswi sedikit lebih paham dibandingkan dengan pertemuan 1.

b. Siklus 2

Siklus 2 pertemuan 1 dilaksanakan pada hari Kamis, tanggal 09 September 2021 di kelas V SD Negeri 002 Rambah Samo yang berjumlah 24 siswa dengan alokasi waktu 2 X 35 menit. Pada penelitian siklus 1 dan 2 ini peneliti didampingi oleh guru kelas $\mathrm{V}$ langsung. Pada saat kegiatan belajar mengajar peneliti bertindak layaknya seorang guru. Kegiatan pembelajaran diawali dengan membuka kelas, mengecek kehadiran dan kesiapan siswa untuk belajar, menyampaikan apersepsi dan menyampaikan tujuan pembelajaran. Masuk ke kegiatan inti guru menyampaikan materi yang akan dipelajari yaitu pada Tema 3 Makanan Sehat, Subtema 2 Pentingnya makanan Sehat Bagi Tubuh, pembelajaran 1. Dalam pembelajaran guru menggunakan media pembelajaran berupa video animasi tentang organ pencernaan dan fungsi pencernaan pada hewan dan manusia. Kemudian secara berkelompok siswa mengamati video tersebut kemudian mendiskusikannya. Langkah-langkah diskusi dan tugas kelompok dapat di unduh siswa dalam aplikasi Clasroom. Peneliti mengawasi dan membantu siswa dalam mengerjakan tugas kelompok. Selanjutnya siswa mempresentasikan hasil diskusi kelompoknya masing-masing kemudian siswa yang lainnya mengomentari dan memberikan pendapatnya. Untuk mengetahui sampai mana pemahaman siswa terhadap materi yang baru dipelajari peneliti memberikan soal evaluasi sebanyak 20 soal di Classroom. Kegiatan penutup peneliti memberikan refleksi kemudian bersama siswa menyimpulkan pembelajaran, memberikan tindak lanjut agar siswa tetap semangat dan rajin belajar di rumah (Aritonang \& Safitri, 2021).

Siklus 1 pertemuan 2 dilaksanakan pada hari Senin, tanggal 13 September 2021 di kelas V SD Negeri 002 Rambah Samo dengan rangkaian kegiatan pembelajaran yang tidak jauh berbeda dengan pertemuan 1, hanya dengan materi dan kegiatan inti yang berbeda. Pada pertemuan 2 membahas materi Tema 3 Makanan Sehat, Subtema 2 Pentingnya makanan Sehat Bagi Tubuh, pembelajaran 4. Pada kegiatan penutup peneliti juga memberikan soal-soal tes sebagai bahan evaluasi pemahaman siswa-siswi mengenai materi pembelajaran yang baru saja dipelajari dengan menggunakan Classroom (Safitri, Pasaribu, Simamora, \& Lubis, 2019). berikut.

Adapun hasil evaluasi siswa pada siklus 2 pertemuan 1 dan 2 dapat dilihat pada tabel 3

Tabel 3. Data Hasil Belajar Siswa Siklus 2

\begin{tabular}{|c|c|c|c|c|c|c|c|}
\hline \multirow[b]{2}{*}{ No } & \multirow[b]{2}{*}{ Nama } & \multirow{2}{*}{$\begin{array}{l}\text { Nilai Siklus } 2 \\
\text { Pertemuan } 1\end{array}$} & \multicolumn{2}{|c|}{ Ketuntasan Pert 1} & \multirow{2}{*}{$\begin{array}{l}\text { Nilai Siklus } 2 \\
\text { Pertemuan } 2\end{array}$} & \multicolumn{2}{|c|}{ Ketuntasan Pert 2} \\
\hline & & & Tuntas & $\begin{array}{l}\text { Tidak } \\
\text { Tuntas }\end{array}$ & & Tuntas & $\begin{array}{c}\text { Tidak } \\
\text { Tuntas }\end{array}$ \\
\hline 1 & AA & 85 & $T$ & & 95 & $T$ & \\
\hline 2 & $\mathrm{Al}$ & 100 & $\mathrm{~T}$ & & 100 & $\mathrm{~T}$ & \\
\hline 3 & AR & 65 & & TT & 80 & $T$ & \\
\hline 4 & AR & 75 & $\mathrm{~T}$ & & 90 & $\mathrm{~T}$ & \\
\hline 5 & AS & 95 & $T$ & & 100 & $T$ & \\
\hline 6 & DHR & 85 & $\mathrm{~T}$ & & 90 & $\mathrm{~T}$ & \\
\hline 7 & DSA & 85 & $T$ & & 85 & $T$ & \\
\hline
\end{tabular}




\begin{tabular}{|c|c|c|c|c|c|c|c|}
\hline 8 & EID & 95 & $T$ & & 90 & $T$ & \\
\hline 9 & HAZ & 85 & $T$ & & 90 & $T$ & \\
\hline 10 & HIR & 95 & $T$ & & 95 & $\mathrm{~T}$ & \\
\hline 11 & $\mathrm{KG}$ & 90 & $T$ & & 100 & $T$ & \\
\hline 12 & MA & 95 & $T$ & & 100 & $T$ & \\
\hline 13 & MA & 85 & $T$ & & 95 & $T$ & \\
\hline 14 & MAPT & 100 & $T$ & & 100 & $T$ & \\
\hline 15 & MAS & 95 & $T$ & & 100 & $T$ & \\
\hline 16 & $\mathrm{NH}$ & 65 & & TT & 70 & & TT \\
\hline 17 & $\mathrm{RR}$ & 90 & $T$ & & 90 & $T$ & \\
\hline 18 & SA & 85 & $T$ & & 95 & $T$ & \\
\hline 19 & SA & 90 & $\mathrm{~T}$ & & 85 & $\mathrm{~T}$ & \\
\hline 20 & SS & 85 & $T$ & & 90 & $T$ & \\
\hline 21 & TFW & 70 & & TT & 80 & $T$ & \\
\hline 22 & W & 80 & $T$ & & 85 & $T$ & \\
\hline 23 & YF & 85 & $T$ & & 95 & $T$ & \\
\hline 24 & $\mathrm{ZH}$ & 70 & & TT & 75 & & TT \\
\hline & -Rata & 85,4 & & & 90,6 & & \\
\hline \multicolumn{3}{|c|}{ Jumlah } & $\begin{array}{c}20 \\
\text { Siswa }\end{array}$ & 4 Siswa & & $\begin{array}{c}22 \\
\text { Siswa }\end{array}$ & 2 Siswa \\
\hline \multicolumn{3}{|c|}{ Persentase \% } & $83 \%$ & $17 \%$ & & $92 \%$ & $8 \%$ \\
\hline
\end{tabular}

\section{Sumber: Hasil Olahan Data 2021}

Berdasarkan tabel 3 di atas, jumlah hasil evaluasi siswa pada siklus 2 pertemuan 1 yang tuntas sebanyak 20 siswa yaitu $83 \%$ dengan nilai rata-rata 85,4 sedangkan yang tidak tuntas sebanyak 4 siswa yaitu $17 \%$. Hasil evaluasi siswa meningkat pada pertemuan kedua dengan jumlah 22 Siswa yang tuntas yaitu 92\% dengan nilai rata-rata 90,6 dan yang tidak tuntas sebanyak 2 siswa yaitu $8 \%$. Banyaknya siswa yang tidak tuntas pada siklus 1 pertemuan 1 dan 2 disebabkan beberapa kendala diantaranya adalah karena media Classroom baru pertama kali digunakan di kelas V SD Negeri 002 Rambah Samo, sehingga siswa masih kurang memahami langkah-langkah penggunaan dari setiap fungsi menu dalam media Classroom. Hal ini tentu menjadi salah satu faktor penghambat lancarnya pembelajaran dikarenakan dalam mengakses materi dan soal-soal latihan harus bisa mengoperasikan aplikasi Classroom. Apabila diamati data dari tabel 3 peningkatan pemahaman dan hasil evaluasi siswa dapat dikategorikan sangat baik, karena dari 24 siswa yang tuntas mencapai 22 orang yaitu $92 \%$ dan yang tidak tuntas sebanyak 2 orang yaitu 2 orang siswa dengan persentase $8 \%$. Sehingga disimpulkan bahwa persentase $92 \%$ termasuk dalam kategori sangat baik. Tabel peningkatan hasil belajar tersebut dapat digambarkan dalam diagram berikut. 


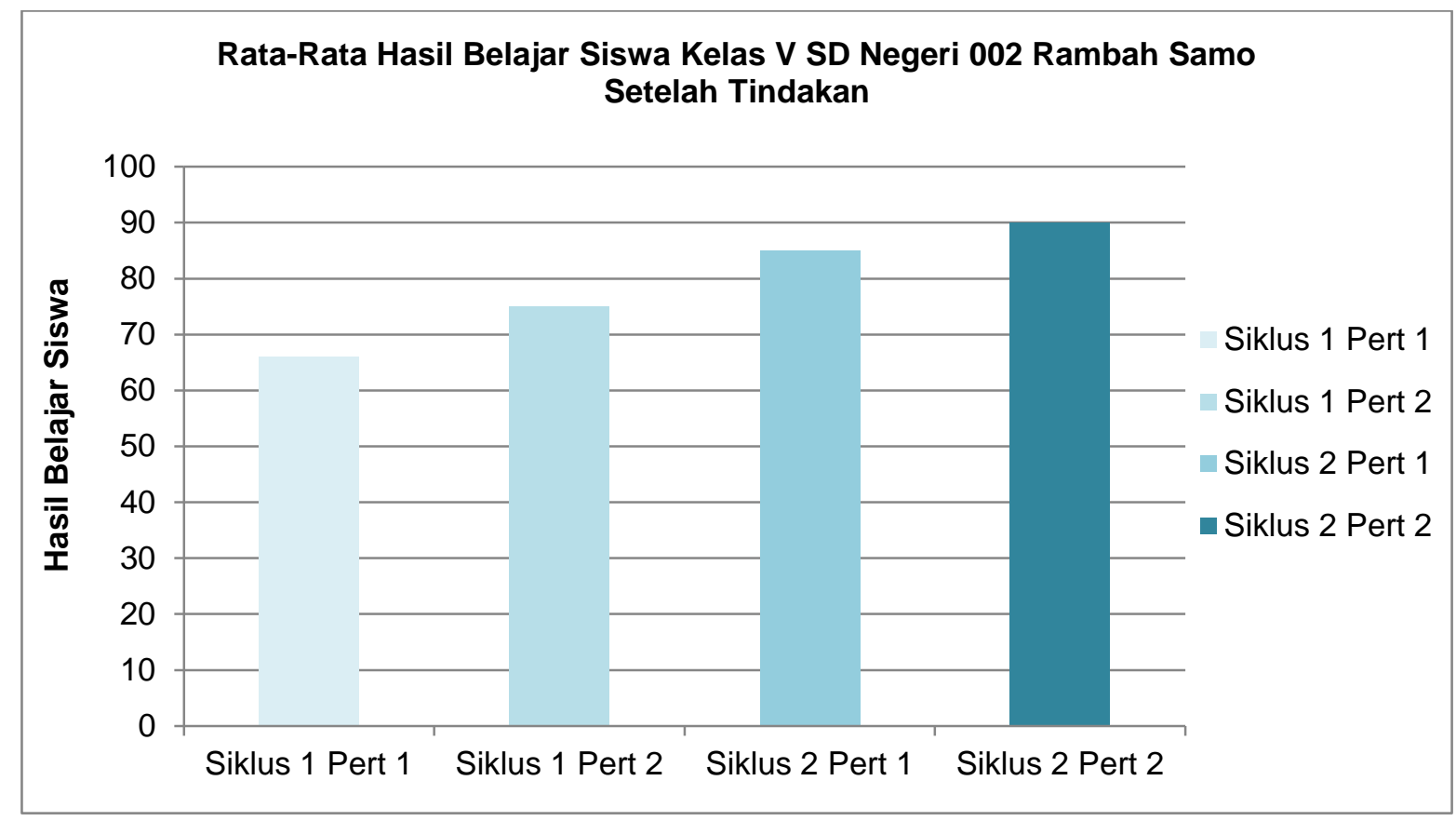

Sumber: Data yang diolah 2021

Gambar 2. Diagram Hasil Belajar Siswa Siklus I dan Siklus II

\section{Pembahasan}

Peneliti melaksanakan penelitian ini sebanyak dua siklus dengan setiap siklus terdiri dari dua kali pertemuan. Setiap pertemuan terdiri atas beberapa tahapan yaitu perencanaan, pelaksanaan, observasi dan refleksi. Tahapan siklus 2 merupakan perbaikan dari tahap siklus 1. Setelah melakukan kegiatan pembelajaran Tematik menggunakan Classroom kemudian memberikan soal evaluasi untuk mengetahui hasil belajar yang diperoleh. Hasil dari kedua siklus tersebut digunakan untuk mengetahui peningkatan hasil belajar siswa SD Negeri 002 Rambah Samo.

Observasi pertama yang dilakukan peneliti saat pembelajaran Tematik kurikulum 2013 di kelas V SD Negeri 02 Rambah Samo belum ideal, masih banyak kendala yang dihadapi guru dalam mengembangkan pembelajaran yang sesuai dengan kurikulum 2013. Banyak siswa yang masih kurang aktif, nilai ulangan harian yang masih di bawah rata-rata dan seharusnya guru adalah hanya sebagai fasilitator bukan teacher center. Siklus 1 dan siklus 2 membahas tentang makanan sehat sehingga peneliti tidak begitu kesulitan untuk mengaitkan proses pembelajaran. Data yang diperoleh sebelum dan sesudah dilaksanakan tindakan menunjukkan adanya peningkatan hasil belajar. Sebelum adanya tindakan dengan menerapkan pembelajara elearning menggunakan classroom pada pembelajaran tematik hasil belajar siswa masih di bawah nilai rata-rata KKM 75. Hasil tes siklus 1 diperoleh sebanyak $67 \%$ atau 16 siswa yang tuntas dan $33 \%$ atau 8 siswa tidak tuntas. Kemudian pada hasil tes siklus 2 diperoleh hasil belajar sebanyak $92 \%$ atau 22 orang yang tuntas dan $8 \%$ atau 2 orang yang tidak tuntas.

Berdasarkan hasil belajar tersebut dapat dikatakan terjadi peningkatan hasil belajar siswa sebesar $25 \%$. Apabila dilihat dari data yang sudah didapat bahwa yang lulus telah melebihi indicator keberhasilan. Maka dapat dinyatakan bahwa penerapan pembelajaran Cooperative ELearning untuk meningkatkan hasil belajar Tematik siswa kelas V SD Negeri 002 Rambah Samo telah berhasil.

\section{Kutipan dan Acuan}

Menurut Komalasari (2013) pembelajaran merupakan suatu sistem atau proses membelajarkan pembelajar yang direncanakan, dilaksanakan dan dievaluasi secara sistematis agar pembelajar dapat mencapai tujuan-tujuan pembelajaran secara efektif dan efisien. Riyanto (2010) mengatakan hakikat pembelajaran kooperatif adalah metode pembelajaran yang 
dirancang untuk melatih kecakapan akademis (academic skills), keterampilan sosial (social skills) dan interpersonal skill. Defenisi e-learning menurut Sutanta (2014) merupakan suatu jenis sistem pembelajaran yang memungkinkan tercapainya bahan ajar ke siswa dengan menggunakan media internet, intranet atau media jaringan komputer lainnya.

Menurut Dimyati dan Mudjiono (2013), hasil belajar adalah proses untuk menentukan nilai belajar siswa melalui kegiatan penilaian atau pengukuran hasil belajar, bertujuan untuk mengetahui tingkat keberhasilan yang dicapai oleh siswa. Hasil belajar sangat penting bagi guru dan juga siswa, karena dari hasil belajar akan muncul nilai yang akan menjadi tolak ukur keberhasilan dalam proses pembelajaran yang telah dilalui. Menurut Trianto (2011) Pembelajaran Tematik adalah pembelajaran terpadu yang menggunakan tema untuk mengaitkan beberapa mata pelajaran sehingga dapat memberikan pengalaman belajar yang bermakna kepada siswa.

\section{KESIMPULAN}

Penerapan pembelajaran Cooperative E-Learning untuk meningkatkan hasil belajar tematik siswa kelas V SD Negeri 002 Rambah Samo. Peningkatan prestasi hasil belajar dapat dilihat dari hasil belajar siswa sebagai berikut: Adanya peningkatan hasil belajar tematik siswa pada setiap siklusnya. Hal ini dibuktikan dengan adanya data dari 2 siklus yang setiap siklusnya terdiri dari dua kali pertemuan. Hasil tes pada pertemuan 1 siklus 1 siswa yang tuntas sebanyak $58 \%$ (14 siswa) dan 42\% (10 siswa) tidak tuntas dengan nilai rata-rata 66,25, meningkat pada pertemuan 2 yaitu dengan jumlah siswa yang tuntas sebanyak $67 \%$ (16 siswa) dan yang tidak tuntas berjumlah $33 \%$ ( 8 siswa) dengan nilai rata-rata 75 . Pada siklus 2 pertemuan 1 yang tuntas sebanyak $83 \%$ (20 siswa) dan yang tidak tuntas sebanyak $17 \%$ (4 siswa) dengan nilai rata-rata 85,4, kemudian mengalami peningkatan pada pertemuan 2 yaitu dengan jumlah yang tuntas sebanyak $92 \%$ (22 siswa) dan yang tidak tuntas sebanyak $8 \%$ (2 siswa) dengan nilai rata-rata 90,6. Dengan adanya peningkatan hasil belajar maka terjadi peningkatan aktivitas guru dan siswa

\section{UCAPAN TERIMA KASIH}

Penelitian ini dapat dilaksanakan dengan baik dan lancar berkat bantuan dari beberapa pihak yang sudah berkontribusi, oleh karena itu peneliti mengucapkan terimakasih kepada pihak yang bersengakutan dalam pembuatan jurnal ini. Terimakasih kepada pihak SD Negeri 002 Rambah Samo, Pembimbing Mata Kuliah Penelitian Tindakan Kelas dan Universitas Labuhan Batu yang sudah mau bekerja sama dengan peneliti dari kampus STKIP Rokania dalam proses penerbitan jurnal pendidikan ini.

\section{DAFTAR PUSTAKA}

Aritonang, I., \& Safitri, I. (2021). Pengaruh Blended Learning Terhadap Peningkatan Literasi Matematika Siswa. Jurnal Cendikia: Jurnal Pendidikan Matematika. Vol 5 No 7, 735-743.

Harahap, Risma Delima (2015) Pengaruh Model Problem Based Learning Terhadap Hasil Belajar Siswa Pada Materi Pokok Perkembangan Manusia Kelas VIISMP N 1 Kualuh Selatan Labupaten Labuhanbatu Utara

Iskandar. (2008). Penelitian Tindakan Kelas. Jambi: Gaung Persada (GP Press).

(2013).Kerangka Dasar Kurikulum 2013. Kementerian Pendidikan dan Kebudayaan Direktorat Jenderal Pendidikan Dasar. Kemendikbud, Jakarta.

Komalasari, K. (2013). Pembelajaran Kontekstual. Bandung: PT. Remaja Rosdakarya.

Mudjiono, D. d. (2013). Belajar dan Pembelajaran. Jakarta: Rineka Cipta. 
Mulyasa. (2009). Praktek Penelitian Tindakan Kelas . Bandung: PT Rosdakarya.

Permendikbud. (2016). Peraturan Menteri Pendidikan dan Kebudayaan Republik Indonesia No. 24 Tahun 2016 Tentang Kompetensi Inti dan Kompetensi Dasar Pelajaran Pada Kurikulum 2013 Pada Pendidikan Dasar dan Pendidikan Menengah.

Rahadian, A. N. (2020). Peningkatan Hasil Belajar IPA Melalui Model E-Learning dengan Media Video pada Siswa Kelas IV MIN 4 Sukoharjo Tahun Pelajaran 2019/2020. IAIN Salatiga.

Riyanto, Y. (2010). Paradigma Baru Pembelajaran Sebagai Referensi Bagi Pendidik dalam Implementasi Pembelajaran yang Efektif dan Berkualitas. Jakarta: Kencana.

Safitri, I., Pasaribu, R., Simamora, S. S., \& Lubis, K. (2019). The Effectiveness of Android Application as a Student Aid Tool in Understanding Physics Project Assignments. Jurnal Pendidikan IPA Indonesia, Vol 8 No 4, 512-520.

Sutanta, E. (2014). Sistem Basis Data. Yogyakarta: Graha Ilmu.

Trianto. (2011). Desain Pembelajaran Tematik Bagi Anak Usia Dini TK/RA dan Anak Usia Awal SD/MI. Jakarta: Kencana Prenada Media Group. 